This document is the Accepted Manuscript version of a Published Work that appeared in final form in Inorganic Chemistry, @ 2016 American Chemical Society after peer review and technical editing by publisher. To access the final edited and published work see Zhou, W., Yu, T., Vazin, M., Ding, J., \& Liu, J. (2016). Cr3+ Binding to DNA Backbone Phosphate and Bases: Slow Ligand

Exchange Rates and Metal Hydrolysis. Inorganic Chemistry, 55(16), 8193-8200. http://dx.doi.org/10.1021/acs.inorgchem.6b01357

\title{
$\mathrm{Cr}^{3+}$ Binding to DNA Backbone Phosphate and Bases: Slow Ligand Exchange Rates and
}

\section{Metal Hydrolysis}

Wenhu Zhou ${ }^{1,2}$, Tianmeng $\mathrm{Yu}^{2}$, Mahsa Vazin ${ }^{2}$, Jinsong Ding $^{1}$ and Juewen Liu ${ }^{1,2, *}$

1. School of Pharmaceutical Sciences, Central South University, Changsha, Hunan, China, 410013.

${ }^{2}$. Department of Chemistry, Waterloo Institute for Nanotechnology, University of Waterloo, Waterloo, Ontario, Canada, N2L 3G1.

*Email: liujw@uwaterloo.ca

Fax: (+1) 519-746-0435

Phone: (+1) 519-888-4567 extension 38919 


\begin{abstract}
The interaction between chromium ions and DNA is of great interest in inorganic chemistry, toxicology, and analytical chemistry. Most previous studies focused on in situ reduction of $\mathrm{Cr}(\mathrm{VI})$, producing $\mathrm{Cr}^{3+}$ for DNA binding. Recently, $\mathrm{Cr}^{3+}$ was reported to activate the $\mathrm{Ce} 13 \mathrm{~d}$ DNAzyme for RNA cleavage. Herein, the Ce13d is used to study two types of $\mathrm{Cr}^{3+}$ and DNA interactions. First, $\mathrm{Cr}^{3+}$ binds to the DNA phosphate backbone weakly through reversible electrostatic interactions, which is weakened by adding competing inorganic phosphate. On the other hand, $\mathrm{Cr}^{3+}$ coordinates with DNA nucleobases forming stable crosslinks that can survive denaturing gel electrophoresis condition. The binding of $\mathrm{Cr}^{3+}$ to different nucleobases was further studied in terms of binding kinetic and affinity by exploiting FAM-labeled DNA homopolymers. Once binding takes place, the stable $\mathrm{Cr}^{3+} / \mathrm{DNA}$ complex cannot be dissociated by EDTA, attributable to the ultra-slow ligand exchange rate of $\mathrm{Cr}^{3+}$. The binding rate follows the order of $\mathrm{G}>\mathrm{C}>\mathrm{T} \approx \mathrm{A}$. Finally, $\mathrm{Cr}^{3+}$ gradually loses its DNA binding ability after storing at neutral or high $\mathrm{pH}$, attributable hydrolysis. This hydrolysis can be reversed by lowering the $\mathrm{pH}$. This work provides a deeper insight into the bioinorganic chemistry of $\mathrm{Cr}^{3+}$ coordination with DNA, clarifies some inconsistency in the previous literature, and offers practically useful information for generating reproducible results.
\end{abstract}




\section{Introduction}

Chromium can exist in nine different oxidation states, with $\mathrm{Cr}^{3+}$ and $\mathrm{Cr}(\mathrm{VI})\left(\mathrm{CrO}_{4}{ }^{2-}\right.$ or $\left.\mathrm{Cr}_{2} \mathrm{O}_{7}{ }^{2-}\right)$ being the most stable forms. While $\mathrm{Cr}^{3+}$ is considered as a nutritional supplement, ${ }^{1} \mathrm{Cr}(\mathrm{VI})$ is highly carcinogenic. ${ }^{2} \mathrm{Cr}(\mathrm{VI})$ readily enters cells by anion transport mechanisms, and its toxicity is attributed to DNA damage. However, $\mathrm{Cr}(\mathrm{VI})$ alone does not damage DNA under physiological buffer conditions without a reducing agent. In one case, microsomes and NADPH were added to mimic the reducing condition in vivo; otherwise little DNA binding was detected. ${ }^{3}$ In vivo, $\mathrm{Cr}(\mathrm{VI})$ can be reduced by biological reducing agents. ${ }^{4,5}$ For example, reduction of $\mathrm{Cr}$ (VI) by ascorbate resulted in DNA binding and cleavage. ${ }^{6}$ Guanine is the most vulnerable base for oxidative damage by $\mathrm{Cr}(\mathrm{V}) .^{7}$ It is generally accepted that the reduction of $\mathrm{Cr}(\mathrm{VI})$ to $\mathrm{Cr}^{3+}$ is responsible for a wide range of $\mathrm{Cr}^{3+}$-DNA adducts, ${ }^{8-11}$ as well as $\mathrm{Cr}(\mathrm{VI})$-related genotoxicity and mutagenicity. ${ }^{12-15}$ Since $\mathrm{Cr}^{3+}$ is the ultimate reason of DNA damage, the direct interaction between $\mathrm{Cr}^{3+}$ and DNA is an important topic. Surprisingly, most previous studies focused on $\mathrm{Cr}(\mathrm{VI})$, while $\mathrm{Cr}^{3+}$ was much less explored.

$\mathrm{Cr}^{3+}$ has a quite unique solution chemistry featured by a very slow ligand exchange rate $\left(\sim 9 \times 10^{-3} \mathrm{~h}^{-1}\right)$ due to its $d^{3}$ electronic configuration in an octahedral ligand field, leading to highly kinetically stable complexes. ${ }^{16}$ Only a few studies touched on the interaction between $\mathrm{Cr}^{3+}$ and nucleosides or DNA. $\mathrm{Cr}^{3+}$ can bind to DNA through both phosphate backbone and nucleobases. The interaction between $\mathrm{Cr}^{3+}$ and nucleotide phosphate was studied by ${ }^{31} \mathrm{P}-\mathrm{NMR} .{ }^{17} \mathrm{Cr}^{3+}$ binding destabilizes the phosphodiester linkages leading to DNA cleavage under alkaline conditions. ${ }^{13}$ $\mathrm{Cr}^{3+}$ prefers to bind cytosine and guanine, ${ }^{18}$ and guanine binds $\mathrm{Cr}^{3+}$ the tightest. ${ }^{3}$ However, Salnikow et al argued that binding is mainly through the phosphate backbone, and the stronger binding of guanine is due to the formation of G-quartets, which facilitate phosphate interaction. ${ }^{19}$ 
A quantitative study showed that the N7 position of guanine and its nearest backbone phosphate chelate $\mathrm{Cr}^{3+}$ with a binding constant of $3150 \mathrm{M}^{-1}{ }^{20}$ The interaction of $\mathrm{Cr}^{3+}$ with double-stranded DNA results in the DNA inter-strand crosslinking. ${ }^{21}$ Because of a strong coordination and slow dissociation kinetics, $\mathrm{Cr}^{3+}$ can form highly stable $\mathrm{Cr}^{3+} / \mathrm{DNA}$ lesions, ${ }^{22}$ inducing its genotoxicity. ${ }^{23}$

The above literature review indicates some inconsistency on the binding mechanism

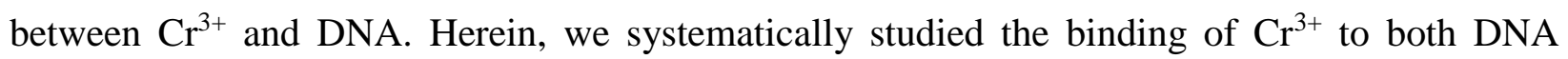
backbone phosphate and nucleobases. Our interest on this topic stems from our recent work on an RNA-cleaving DNAzyme named Ce13d that can use $\mathrm{Cr}^{3+}$ as a metal cofactor. ${ }^{24}$ DNAzymes are DNA-based catalysts. ${ }^{25-28}$ The role of $\mathrm{Cr}^{3+}$ in the Ce13d DNAzyme is to bind to the scissile phosphate. ${ }^{29}$ Given this mechanism, we studied the phosphate backbone binding via DNAzyme cleavage activity, and the nucleobases coordination was characterized through $\mathrm{Cr}^{3+}$-induced DNAzyme inter-strand crosslinking and fluorescence quenching. During our experiment, we noticed the effect of $\mathrm{Cr}^{3+}$ hydrolysis. These results provide a solid basis for further studies of the $\mathrm{Cr}^{3+} / \mathrm{DNA}$ bioinorganic chemistry.

\section{Materials and methods.}

Chemicals. The DNA samples were purchased from Eurofins (Huntsville, AL), and their sequences and modifications are showed in Table 1. All of the metal salts were from SigmaAldrich and the buffers were from Mandel Scientific (Guelph, ON, Canada). All the solutions were prepared using Milli-Q water. 
Table 1. DNA oligonucleotides used in this study. The cleavage site ribo-adenine is denoted by rA, FAM = carboxyfluorescein.

\begin{tabular}{cc}
\hline DNA name & Sequence and modifications (from 5'-end) \\
\hline Ce13d & TTTCGCCATAGGTCAAAGGTGGGTGCGAGTTTTTACTCGTTATAGTGACTCGTGAC \\
Inactive mutant & TTTCGCCATAGGTCAAAGTTGGGTGCGAGTTTTTACTCGTTATAGTGACTCGTGAC \\
Sub-FAM & GTCACGAGTCACTATrAGGAAGATGGCGAAA-FAM \\
FAM-A10 & FAM-AAAAAAAAAA \\
FAM-T10 & FAM-TTTTTTTTTT \\
FAM-C10 & FAM-CCCCCCCCCC \\
FAM-G10 & FAM-GGGGGGGGGG \\
\hline
\end{tabular}

DNAzyme activity assay. In a typical Ce13d activity assay, the enzyme strand $(2 \mu \mathrm{M})$ and FAM labeled substrate $(1 \mu \mathrm{M})$ were mixed in buffer $(25 \mathrm{mM} \mathrm{NaCl}, 50 \mathrm{mM}$ buffer with different pH's $)$. The complex was annealed by heating at $95{ }^{\circ} \mathrm{C}$ for $3 \mathrm{~min}$ followed by slow cooling to room temperature over $30 \mathrm{~min}$. Then, $1 \mu \mathrm{L}$ metal solution was added to $9 \mu \mathrm{L}$ DNAzyme to initiate the cleavage reaction. At designated time points, an aliquot of the sample was transferred to $8 \mathrm{M}$ urea containing $1 \times$ gel loading dye to quench the reaction. The cleavage product was then separated by a $15 \%$ denaturing polyacrylamide gel (dPAGE) and the results were analyzed using a Bio-Rad ChemiDoc MP imaging system.

DNA binding with $\mathrm{Cr}^{3+}$. To study DNA and $\mathrm{Cr}^{3+}$ binding, $\mathrm{Cr}^{3+}(1 \mathrm{mM}, 1 \mu \mathrm{L})$ and FAM-labeled DNA $(10 \mu \mathrm{M}, 1 \mu \mathrm{L})$ were mixed in buffer $(25 \mathrm{mM} \mathrm{NaCl}, 50 \mathrm{mM}$ MES, pH 6.5, $9 \mu \mathrm{L})$. At each time point, the reaction was stopped by adding $1 \mu \mathrm{L}$ EDTA $(10 \mathrm{mM})$. Then, the samples were analyzed using the dPAGE as described above. 
$\mathbf{C r}^{3+}$ hydrolysis assay. $\mathrm{Cr}^{3+}(1 \mathrm{mM}, 2 \mu \mathrm{L})$ was added to buffers $(5 \mathrm{mM}, 14 \mu \mathrm{L})$ of various $\mathrm{pH}$ 's. After incubation for a designated time, the $\mathrm{pH}$ was adjusted by adding MES $(2 \mu \mathrm{L}, 500 \mathrm{mM}, \mathrm{pH}$ 6.5). Then, $2 \mu \mathrm{L}$ of the FAM-abeled C10 DNA $(10 \mu \mathrm{M})$ was immediately added, followed by $2 \mathrm{~h}$ incubation. The reaction was stopped by EDTA $(10 \mathrm{mM}, 2 \mu \mathrm{L})$. Afterwards, HEPES buffer (50 $\mathrm{mM}, 80 \mu \mathrm{L}$ ) was added, and the fluorescence intensity at $525 \mathrm{~nm}$ was monitored in a 96-well plate with a microplate reader (M3, SpectraMax) by exciting at $485 \mathrm{~nm}$. To acidify the solution, each $20 \mu \mathrm{L} \mathrm{Cr}^{3+}$ sample was added with $\mathrm{HCl}(0.1 \mathrm{M}, 1 \mu \mathrm{L})$ for $1 \mathrm{~h}$ incubation.

\section{Results and Discussion}

The Ce13d DNAzyme and its mechanism. The secondary structure of the Ce13d DNAzyme is shown in Figure 1A. Its substrate strand contains a single RNA (denoted by rA). The 2'-OH group of this RNA nucleotide acts as an internal nucleophile to attack the scissile phosphate, forming a highly negatively charged phosphorane intermediate. Ce13d is similarly active with all the trivalent lanthanide ions and $\mathrm{Y}^{3+}$, moderately active with $\mathrm{Pb}^{2+}\left(\sim 20\right.$-fold slower than $\left.\mathrm{Ce}^{3+}\right),{ }^{29}$ and weakly active with $\mathrm{Cr}^{3+}\left(\sim 150\right.$-fold slower than $\left.\mathrm{Ce}^{3+}\right) \cdot{ }^{30}$ Once the scissile phosphate is replaced by a phosphorothioate linkage, it becomes active with thiophilic metals such as $\mathrm{Cd}^{2+}$, $\mathrm{Cu}^{2+}$, and $\mathrm{Hg}^{2+}{ }^{29,31}$ Therefore, the role of the metals, including $\mathrm{Cr}^{3+}$, is to neutralize the negative charges built in the transition state (Figure 1B). Since Ce13d is the only known DNAzyme that works with $\mathrm{Cr}^{3+}$, it provides a unique opportunity to study the interaction between $\mathrm{Cr}^{3+}$ and the DNA phosphate. This information can be obtained by measuring the cleavage activity of the Ce13d DNAzyme. 
The $\mathrm{H}_{2} \mathrm{O}$ and $\mathrm{Cl}^{-}$exchange does not affect $\mathrm{Cr}^{3+}$ activity. $\mathrm{Cr}^{3+}$ has a very slow ligand exchange rate due to its $d^{3}$ electronic configuration, and this can be explained by the octahedral crystal field stabilization energy theory. ${ }^{16}$ A consequence is the extremely slow dissolution of anhydrous salt of $\mathrm{CrCl}_{3}$, due to the slow exchange of $\mathrm{Cl}^{-}$by water. In this study, we used chromium trichloride hexahydrate as the $\mathrm{Cr}^{3+}$ source, which strictly speaking has a formula of $\left[\mathrm{CrCl}_{2}\left(\mathrm{H}_{2} \mathrm{O}\right)_{4}\right] \cdot \mathrm{Cl}\left(\mathrm{H}_{2} \mathrm{O}\right)_{2} \cdot{ }^{32}$ After dissolving this salt, the solution gradually changed its color from green to blue/violet over 3 months due to the formation of $\left[\mathrm{CrCl}\left(\mathrm{H}_{2} \mathrm{O}\right)_{5}\right] \cdot \mathrm{Cl}_{2}\left(\mathrm{H}_{2} \mathrm{O}\right)$. The time needed for this color change also exemplifies slow exchange (Figure 1C, upper panel). When testing these $\mathrm{Cr}^{3+}$ samples with $\mathrm{Ce} 13 \mathrm{~d}$, they all induced a similar amount of cleavage (Figure 1C, lower panel). We measured the cleavage kinetics of the freshly prepared and 3month old $\mathrm{Cr}^{3+}$ samples, each yielding a similar cleavage rate of $1.0 \mathrm{~h}^{-1}$ (Figure 1D). Therefore, the exchange of $\mathrm{Cl}^{-}$by water has little effect on the DNAzyme activity, suggesting that both species interact similarly with the DNA phosphate.
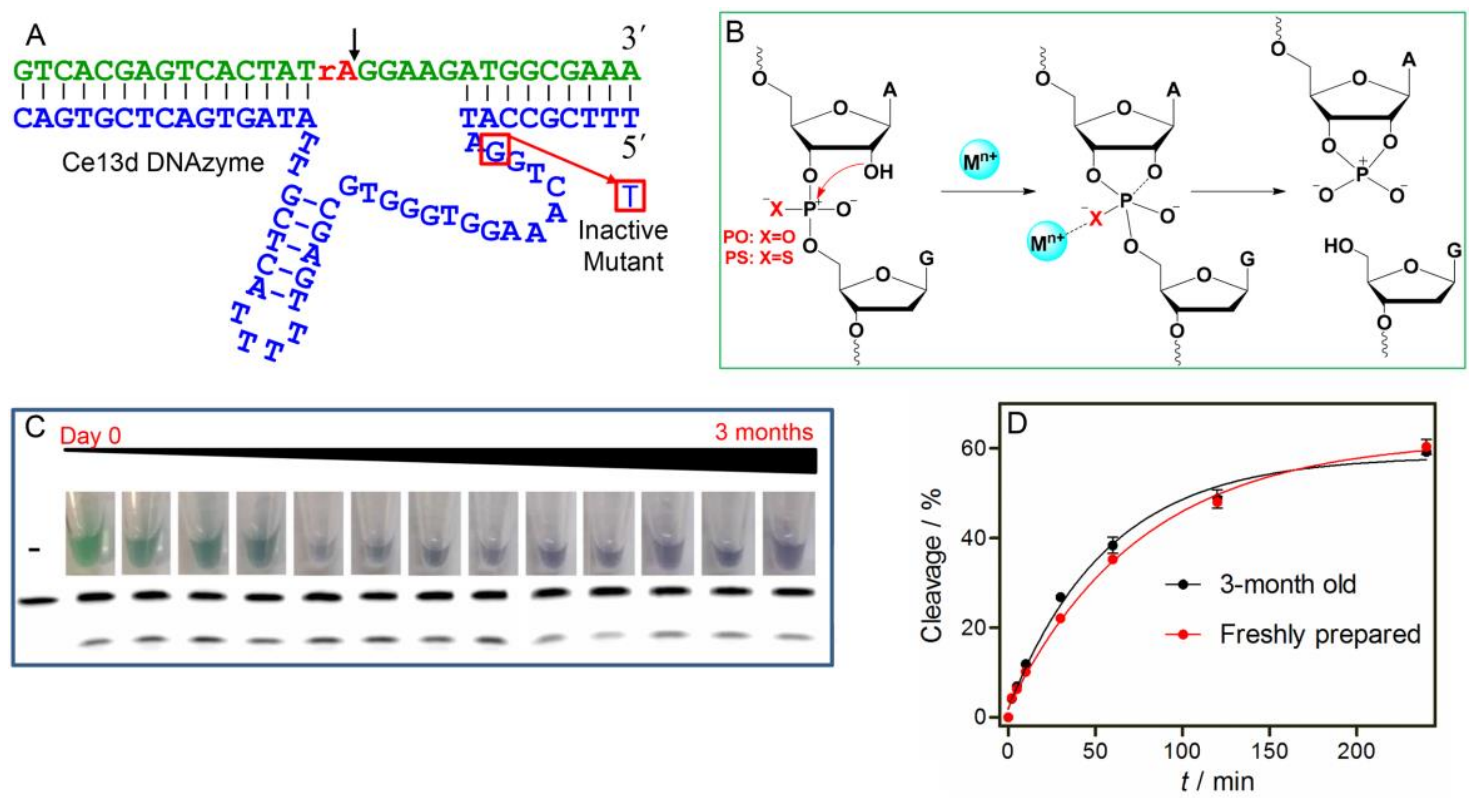
Figure 1. (A) The secondary structure of the Ce13d DNAzyme and an inactive mutant with a single point mutation. The arrowhead indicates the cleavage site in the substrate strand, and rA denotes for ribo-adenine. (B) The general mechanism of RNA cleavage. The $2^{\prime}-\mathrm{OH}$ acts as an internal nucleophile to attack the scissile phosphate and the role of metal ions is to stabilize the phosphorane transition state. (C) Photographs of the chromium chloride salt dissolved in water from freshly prepared to 3-month old. The bottom panel is the cleavage activity of each tube displayed. They all showed a similar cleavage yield (reaction performed in $25 \mathrm{mM} \mathrm{NaCl}, 50 \mathrm{mM}$ MES, pH 6.0 for $1 \mathrm{~h}$ ). (D) Kinetics of substrate cleavage using the freshly prepared and 3-month old $\mathrm{Cr}^{3+}$ samples (the final $\mathrm{Cr}^{3+}$ concentration was $100 \mu \mathrm{M}$ ).

Effect of pH. pH is an important factor governing DNA/metal interaction. In particular, in the context of RNA cleavage, higher $\mathrm{pH}$ is often associated with higher cleavage rates due to facilitated deprotonation of the 2'-OH nucleophile. We measured the cleavage kinetics of the Ce13d at different pH's and their gel images are shown in Figure 2A. This assay was carried out with a FAM-labeled substrate, and we expected to observe two bands in each lane: the uncleaved substrate and the cleavage product. Interestingly, some higher molecular weight bands also appeared, especially between $\mathrm{pH} 6.0$ and 7.0. The origin of these higher bands will be discussed later, and here we first analyzed the $\mathrm{pH}$-dependent cleavage activity.

The relative intensity of the bottom two bands was quantified (Figure 2B), from which the cleavage rate was plotted it as a function of $\mathrm{pH}$ (Figure 2C). Interesting, the activity is quite insensitive to $\mathrm{pH}$ at slightly acidic conditions (Figure $2 \mathrm{C}$, black dots). The highest rate is at $\mathrm{pH}$ $7.0\left(\sim 1.3 \mathrm{~h}^{-1}\right)$. However, at this $\mathrm{pH}$, the final yield is only $\sim 40 \%$, which may lead to artifacts in 
the rate fitting. Further increasing the $\mathrm{pH}$ to 7.6 substantially decreased the cleavage rate. We previously studied the effect of $\mathrm{pH}$ using $\mathrm{Ce}^{3+}$, and the cleavage rate increased linearly with a slope of $\sim 0.4$ in the $\mathrm{pH}$ range of 5.6-6.8 (Figure $2 \mathrm{C}$, yellow dots). ${ }^{29}$ The lower $\mathrm{pH}$ sensitivity here might be due to hydrolysis of $\mathrm{Cr}^{3+}$, which cancels the general promoting effect of $\mathrm{pH}$ for RNA cleavage.
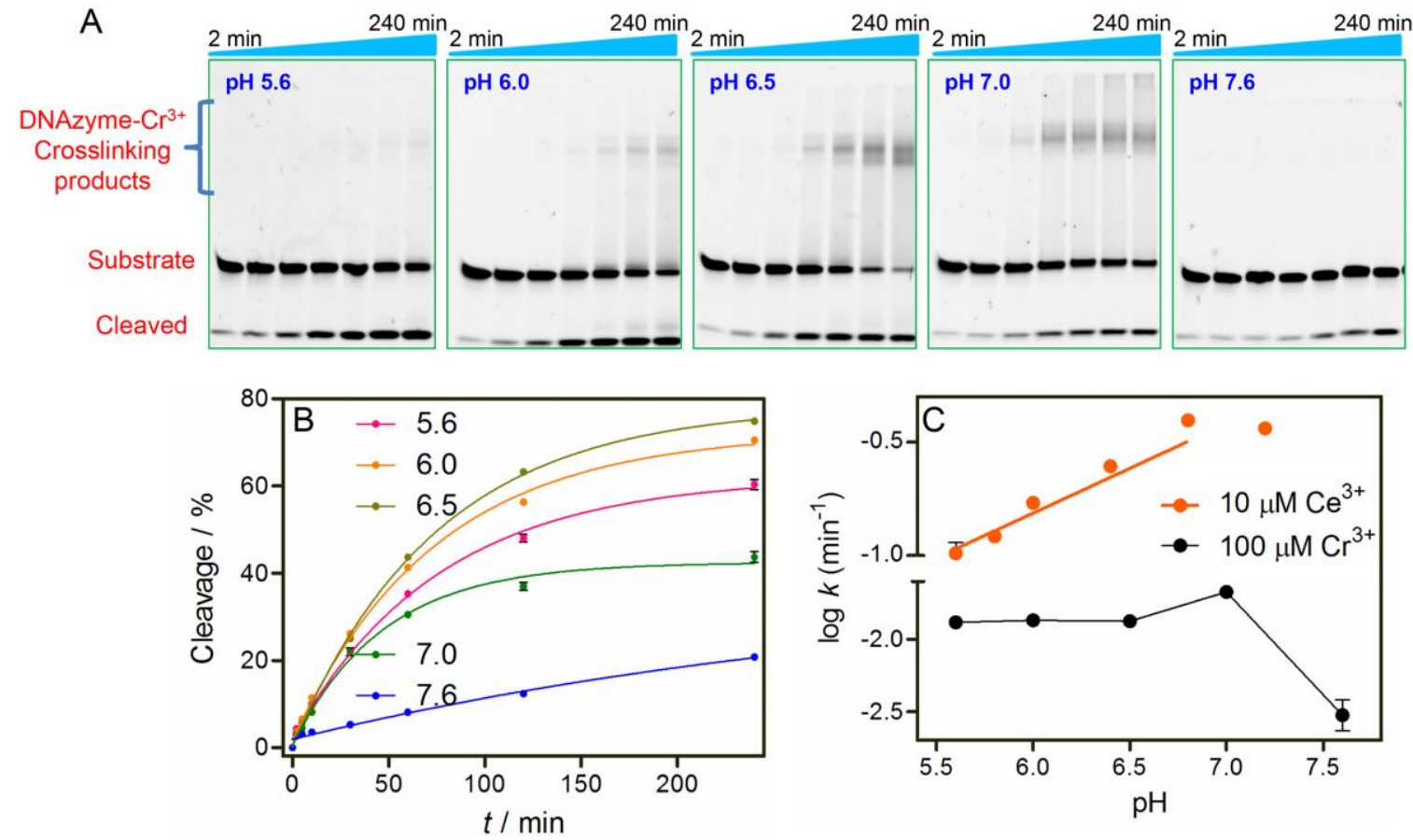

Figure 2. (A) Gel images showing the reaction kinetics of $1 \mu \mathrm{M} \mathrm{Ce} 13 \mathrm{~d}$ in the presence of 100 $\mu \mathrm{M} \mathrm{Cr}^{3+}$ at different $\mathrm{pH}$ 's. The assay was carried out in $25 \mathrm{mM} \mathrm{NaCl}$ with $50 \mathrm{mM}$ buffer (MES: pH 5.6-7.0; MOPS: pH 7.6). (B) Cleavage kinetics of Ce13d with $100 \mu \mathrm{M} \mathrm{Cr}^{3+}$ at different pH's. (C) The rate-pH profile of Ce13d with $100 \mu \mathrm{M} \mathrm{Cr}^{3+}$ or $10 \mu \mathrm{M} \mathrm{Ce}^{3+}$.

DNA crosslinked by $\mathbf{C r}^{3+}$. Next, we shifted our attention to the smeared higher bands in Figure 2A. To identity their origin, we performed the same reaction using the FAM-labeled substrate 
alone without the enzyme strand (Figure 3A), where we observed mainly fluorescence quenching with a slightly slower gel running, suggesting those smeared products in Figure 2A must involve also the enzyme strand. Note that the FAM label was only on the substrate, while the enzyme was non-labeled.

Since the Ce13d cleaves the substrate in presence of $\mathrm{Cr}^{3+}$ and this complicates our analysis, we next used an inactive Ce13d mutant (Figure 1A). With this single nucleotide mutation, no cleavage was produced with $\mathrm{Ce}^{3+},{ }^{29}$ and $\mathrm{Cr}^{3+}$ should also be inactive. Interestingly, the same smeared higher molecular weight bands were also observed (Figure 3B). Therefore, this feature is independent of the cleavage reaction. The only reasonable explanation is that $\mathrm{Cr}^{3+}$ can crosslink double-stranded DNA to form a stable complex. Once formed, it can survive the harsh condition of denaturing gel electrophoresis (e.g. with EDTA and $8 \mathrm{M}$ urea). DNA inter-strand crosslinking by $\mathrm{Cr}^{3+}$ was observed under certain in vitro conditions. ${ }^{13,33}$ This product is usually used to explain cell cycle arrest by the reduction of $\mathrm{Cr}(\mathrm{VI})$, since stable crosslinking products can block the unwinding of duplex DNA and thus DNA replication. ${ }^{34,35}$

It is also interesting to note that without cleavage, all the substrate strands converted to the crosslinked product in $4 \mathrm{~h}$ (Figure 3B). With cleavage (Figure 2A), there is a competition between the crosslinking reaction and the cleavage reaction. We reason that the FAM bearing fragment is released from the enzyme after cleavage, ${ }^{24}$ and thus cannot be crosslinked with the enzyme, which is the basis of the competition.

The crosslinking reaction is most pronounced at $\mathrm{pH} 6.5$ and $\mathrm{pH}$ 7.0. Even at these optimal $\mathrm{pH}$ values, however, the crosslinking kinetics is still relatively slow (requiring $1 \mathrm{~h}$ to complete at $\mathrm{pH}$ 7). To have a quantitative understanding, we plotted the kinetics of crosslinking (Figure 3C), and further extracted the crosslinking rate as a function of $\mathrm{pH}$ (excluding $\mathrm{pH}$ 7.6). A faster rate 
was observed at higher $\mathrm{pH}$ (Figure 4D), which is consistent with a previous study showing that the ligand exchange rate of $\mathrm{Cr}^{3+}$ is faster under higher $\mathrm{pH}^{36}$ The lack of crosslinking at $\mathrm{pH} 7.6$ may be due to $\mathrm{Cr}^{3+}$ hydrolysis (vide infra).
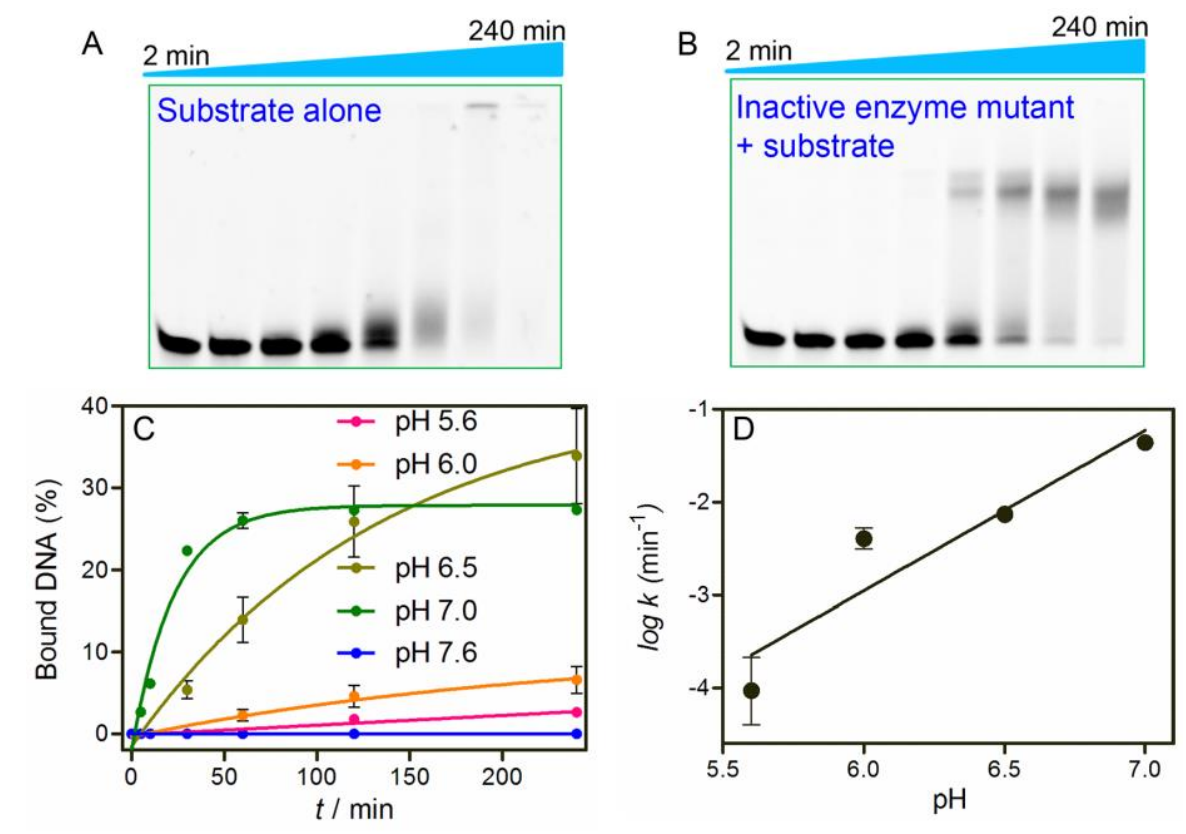

Figure 3. Gel images of $\mathrm{Cr}^{3+}$ binding with (A) the substrate alone and (B) the inactive mutated DNAzyme complex. The assay was performed in buffer (25 mM NaCl, $50 \mathrm{mM} \mathrm{MES}, \mathrm{pH}$ 6.5). (C) Kinetics of crosslinking the Ce13d complex with $100 \mu \mathrm{M} \mathrm{Cr}^{3+}$ at different $\mathrm{pH}$ 's. (D) The $\log$ of DNA crosslinking rate calculated from (C) as a function of $\mathrm{pH}$.

Adding inorganic phosphate to pre-incubated $\mathbf{C r}^{3+} / \mathbf{D N A z y m e}$. The inorganic phosphate was previously shown to dissociate $\mathrm{Cr}^{3+} / \mathrm{DNA}$ binding. ${ }^{13,37}$ On the other hand, we recently used phosphate to mask other metal ions, leaving $\mathrm{Cr}^{3+}$ to be the only active metal for the $\mathrm{Ce} 13 \mathrm{~d}$ DNAzyme. ${ }^{30}$ It is also known that $\mathrm{Cr}^{3+}$ needs to interact with the scissile phosphate to facilitate the cleavage reaction of the $\mathrm{Ce} 13 \mathrm{~d} .{ }^{29}$ Based on these, we next used free inorganic phosphate to 
probe the binding between $\mathrm{Cr}^{3+}$ and the DNAzyme. First, the DNAzyme was pre-incubated with $\mathrm{Cr}^{3+}$, and then phosphate was added to test if the pre-formed $\mathrm{Cr}^{3+} / \mathrm{DNAzyme}$ complex can be dissociated.

To probe phosphate backbone binding (quantified by substrate cleavage), the Ce13d was pre-incubated with $\mathrm{Cr}^{3+}$ at $\mathrm{pH} 5.5$ for $1 \mathrm{~h}$ (under this $\mathrm{pH}$ the crosslinking reaction was minimized). In addition, no $\mathrm{Na}^{+}$was included in the buffer to avoid cleavage at this incubation step. Note that $\mathrm{Ce} 13 \mathrm{~d}$ also requires $\mathrm{Na}^{+}$for activity. ${ }^{38,} 39$ Then, free phosphate was added together with $\mathrm{Na}^{+}$, followed by $1 \mathrm{~h}$ incubation to induce the cleavage reaction. A low concentration (e.g. $<5 \mathrm{mM}$ ) of phosphate has little effect on the activity of the DNAzyme, while the cleavage yield started to decrease beyond $5 \mathrm{mM}$ phosphate (Figure $4 \mathrm{~A}$, blue trace). The result suggests that $\mathrm{Cr}^{3+}$ binds to the DNA phosphate reversibly, and such binding can be dissociated by competition from a high concentration of free phosphate.
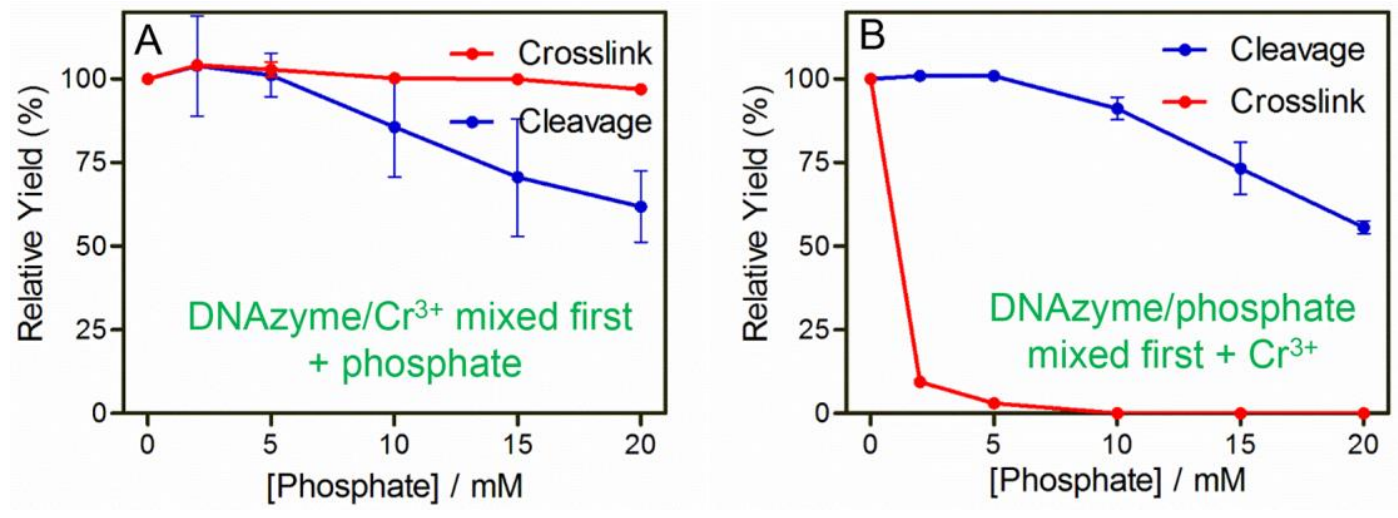

Figure 4. Relatively cleavage and crosslinking yield of the Ce13d in the presence of various concentrations of inorganic phosphate when (A) the DNAzyme and $\mathrm{Cr}^{3+}$ were mixed before adding phosphate, and (B) the DNAzyme and phosphate were mixed before adding $\mathrm{Cr}^{3+}$. In (A) $100 \mu \mathrm{M} \mathrm{Cr}{ }^{3+}$ was pre-incubated with $1 \mu \mathrm{M}$ DNAzyme for $1 \mathrm{~h}$, followed by adding phosphate for $1 \mathrm{~h}$. In (B), $100 \mu \mathrm{M} \mathrm{Cr}^{3+}$ was added to a mixture of phosphate and $1 \mu \mathrm{M}$ DNAzyme for $1 \mathrm{~h}$. For 


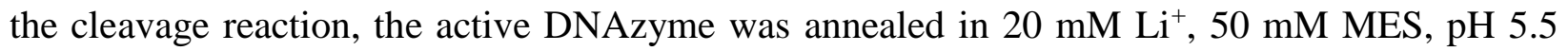
( $\mathrm{pH}$ adjusting by $\mathrm{LiOH}$ and $\mathrm{HCl}$ ). Then, $20 \mathrm{mM} \mathrm{Na}^{+}$was added to initiate the cleavage reaction. For the crosslinking reaction, the inactive DNAzyme mutant was annealing in $20 \mathrm{mM} \mathrm{Na}^{+}, 50$ mM MES, pH 6.5.

To probe the crosslinking reaction, the inactive Ce13d mutant was used and the $\mathrm{pH}$ was adjusted to 6.5 to promote crosslinking. In contrast to the cleavage reaction, the crosslinking yield was almost unchanged with phosphate concentration up to $20 \mathrm{mM}$ (Figure 4A, red trace), indicating that the crosslinking products are quite stable (e.g. irreversible binding). Since the crosslinked DNA is not affect by phosphate, we reason that the crosslinking is likely through nucleobases instead of the phosphate backbone of DNA.

Adding $\mathrm{Cr}^{3+}$ to the DNAzyme/phosphate mixture. We further switched the order of addition. The DNAzyme was mixed with different concentrations of phosphate first followed by adding $\mathrm{Cr}^{3+}$, directly observing the competition. The cleavage yield has a quite similar trend (Figure 4B, blue trace), further confirming the reversible and quite weak binding to the phosphate. In contrast, the pattern of the crosslinking reaction is totally different. Although phosphate failed to dissociate the crosslinked DNA, it strongly inhibited the crosslinking reaction. With $5 \mathrm{mM}$ phosphate, almost no crosslinking was observed (Figure 4B, red trace). We attribute it to the slow binding kinetic of the crosslink reaction, and $\mathrm{Cr}^{3+}$ kinetically prefers to bind with phosphate due to its high concentration (the DNAzyme concentration was only $1 \mu \mathrm{M}$ ).

A few conclusions can be drawn from the above experiments using free phosphate as a probe. $\mathrm{Cr}^{3+}$ binds the DNA phosphate reversibly and weakly, while the crosslinking of DNA 
bases by $\mathrm{Cr}^{3+}$ is strong and irreversible. It is likely that $\mathrm{Cr}^{3+}$ binds to phosphate through electrostatic interaction, in which the original coordination sphere of $\mathrm{Cr}^{3+}$ remains intact. In addition, we also studied the effect of $\mathrm{Na}^{+}$concentration on the cleavage kinetic (Figure S1A). While Ce13d requires $\mathrm{Na}^{+}$, a decrease of the cleavage rate with higher $\mathrm{Na}^{+}$concentration was observed (Figure S1B), likely due to the charge screening effect of $\mathrm{Na}^{+}$as a salt. Therefore, for $\mathrm{Cr}^{3+}$ binding to DNA phosphate, the affinity is mostly governed by weak electrostatic attraction. On the other hand, the DNA crosslinking reaction is through $\mathrm{Cr}^{3+}$ inner sphere binding. In this case, some ligands on $\mathrm{Cr}^{3+}$ are displaced by nucleobases, yielding highly stable complexes that cannot be associated by inorganic phosphate.

Effect of DNA sequence. After understanding the interaction between $\mathrm{Cr}^{3+}$ and DNA phosphate, we next focused our attention on DNA bases. The data already indicate that $\mathrm{Cr}^{3+}$ can stably coordinate with DNA bases, and the products can survive denaturing gel electrophoresis condition. Next, we further studied the effect of different DNA bases using FAM-labeled 10-mer DNA homopolymers. Each DNA $(1 \mu \mathrm{M})$ was separately incubated with $100 \mu \mathrm{M} \mathrm{Cr}^{3+}$. Since $\mathrm{Cr}^{3+}$ quenches the labeled fluorophore after binding, we used the gel band intensity to quantify $\mathrm{Cr}^{3+}$ binding. With a longer incubation time, the band intensity gradually decreased (Figure 5A), and the results are quantified in Figure 5B. Among the four DNAs, the G10 DNA binds to $\mathrm{Cr}^{3+}$ the fastest, with a rate of $3.1 \mathrm{~h}^{-1}$. The binding rate of each homo-DNA follows the order of $\mathrm{G}>\mathrm{C}>$ $\mathrm{T} \approx \mathrm{A}$, although the difference is quite moderate (within 5-fold). In addition, all the DNA sequences reached full $\mathrm{Cr}^{3+}$ binding in $4 \mathrm{~h}$. Therefore, each type of nucleobase is capable of coordinating with $\mathrm{Cr}^{3+}$ with high stability. This kinetic difference among different DNAs also suggests that $\mathrm{Cr}^{3+}$ exerts its quenching function mainly through DNA base binding instead of directly interacting with the FAM fluorophore. 
Binding strength/reversibility probed by EDTA. To probe the binding affinity of different DNA bases, we used EDTA as a competitor, which should bind $\mathrm{Cr}^{3+}$ much stronger than phosphate does. When $100 \mu \mathrm{M} \mathrm{Cr}^{3+}$ was added to the mixtures of DNA $(1 \mu \mathrm{M})$ and EDTA (10 $\mathrm{mM}$ ), no decrease in band intensity was observed for all sequences (Figure 5C, lane 1 and lane 2), suggesting that EDTA inhibited $\mathrm{Cr}^{3+}$ binding with DNA. It is likely that EDTA binding is kinetically favored due to its much higher concentration than DNA, just like the above phosphate inhibition experiment.

Next, we tested whether the pre-formed $\mathrm{Cr}^{3+} / \mathrm{DNA}$ complex can be dissociated by EDTA. For this purpose, $100 \mu \mathrm{M} \mathrm{Cr}^{3+}$ was incubated with $1 \mu \mathrm{M}$ DNA to form the complex. Then a high concentration of EDTA $(10 \mathrm{mM})$ was added. This time, EDTA failed to recover the DNA fluorescence (Figure 5C, lane 3), suggesting that DNA-Cr ${ }^{3+}$ complex did not dissociate even in the presence of EDTA. Further quantification indicates that EDTA has little effect on the stability of $\mathrm{Cr}^{3+} / \mathrm{DNA}$ conjugates, suggesting that the complex is highly stable (Figure 5D).

Such strong binding suggests the formation of metallated DNA. We previously tested various metal ions $\left(\mathrm{Cr}^{3+}\right.$ was not included) with DNA, where only $\mathrm{Pt}^{2+}$ formed stable metallated DNA adduct. ${ }^{40}$ The ligand exchange rate of $\mathrm{Cr}^{3+}$ is about 100 -fold slower than that of $\mathrm{Pt}^{2+},{ }^{16}$ and thus $\mathrm{Cr}^{3+}$ should have even higher DNA binding stability. Because of such irreversible binding for all the DNA sequences, we cannot quantitatively study the binding strength of each base. Our result confirmed that the binding observed here is through DNA base rather than phosphate backbone, since EDTA can dissociate the phosphate backbone binding. ${ }^{19}$

Binding affinity with different bases. The apparent dissociation constant $\left(K_{\mathrm{d}}\right)$ of each DNA homopolymer was measured by respectively incubating them with various concentrations of $\mathrm{Cr}^{3+}$ for $4 \mathrm{~h}$. The apparent binding affinity showed a similar trend to that of the binding kinetic, with 
$\mathrm{G}>\mathrm{C}>\mathrm{T} \approx \mathrm{A}$ (Figure 5E). In a parallel experiment, a longer incubation time of $24 \mathrm{~h}$ was carried out, where the relative affinity still followed the same order, but the absolute affinity of each base increased (Figure 5F). This can be explained by the irreversible binding between $\mathrm{Cr}^{3+}$ and DNA. Once formed, it cannot dissociate, and thus binding kinetics governed the reaction. In addition, with a longer incubation time, more $\mathrm{Cr}^{3+}$ was bound, resulting in higher apparent binding affinity.

After $24 \mathrm{~h}$ reaction, the binding of the G10 DNA is saturated at $\sim 20 \mu \mathrm{M} \mathrm{Cr}^{3+}$, with a $K_{\mathrm{d}}$ of $4 \mu \mathrm{M} \mathrm{Cr}{ }^{3+}$ (Figure 5F). The binding constant between $\mathrm{Cr}^{3+}$ and DNA was previously measured to be $3150 \mathrm{M}^{-1}$ or $K_{\mathrm{d}}=310 \mu \mathrm{M} \mathrm{Cr}^{3+},{ }^{20}$ which was much weaker than what we measured here. A few factors can give rise to such a difference. First, we used ssDNA, which is more effective for $\mathrm{Cr}^{3+}$ binding, while dsDNA was used previously. Second, the reaction time was significantly different $\left(24 \mathrm{~h}\right.$ versus $2 \mathrm{~h}$ ). In addition, we used a higher concentration of $\mathrm{Cr}^{3+}$ stock solution and the reaction $\mathrm{pH}$ was strictly controlled at 6.5 . As it will be discussed later, these two factors also have a strong effect on DNA binding. It needs to be pointed out that even our $K_{\mathrm{d}}$ value is still a conservative estimation. The true binding constant should be extremely high given the irreversible nature of $\mathrm{Cr}^{3+}$ binding to DNA. All these measurements (including ours) are kinetically limited, and likely we did not reach the true equilibrium. We did not further extend the incubation time since $\mathrm{Cr}^{3+}$ gradually hydrolyzes around $\mathrm{pH} 6.5$ (vide infra), which complicates the data analysis. 
A $\quad t(\min )=$

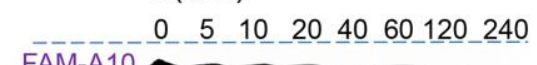
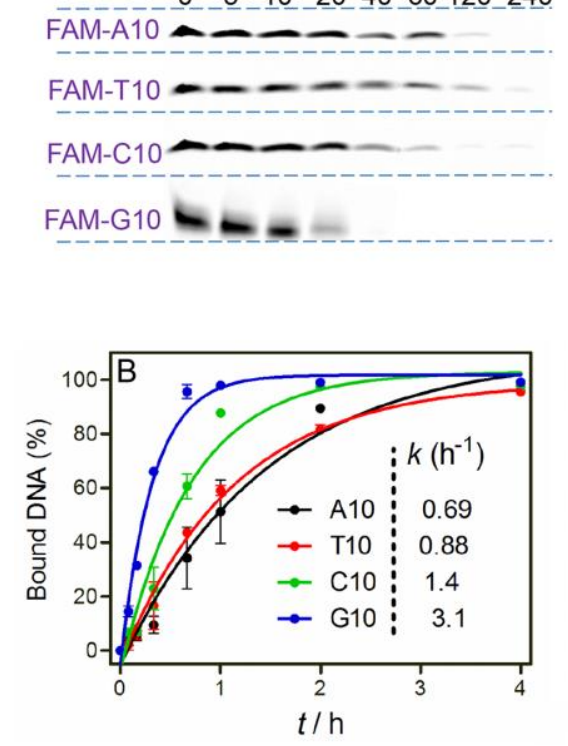

C

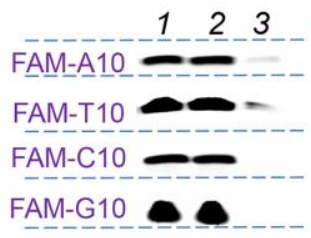

Lane1: DNA alone

Lane2: DNA/EDTA + $\mathrm{Cr}^{3+}$

Lane3: DNA/ $\mathrm{Cr}^{3+}+$ EDTA

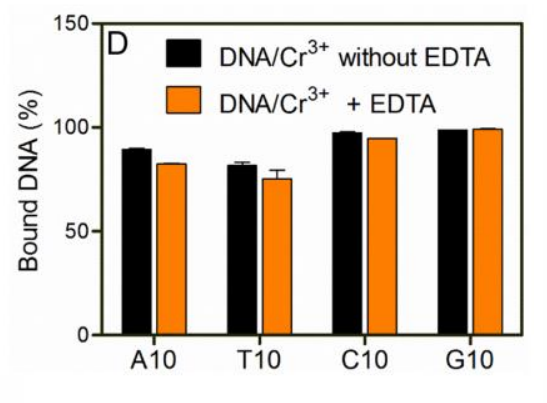

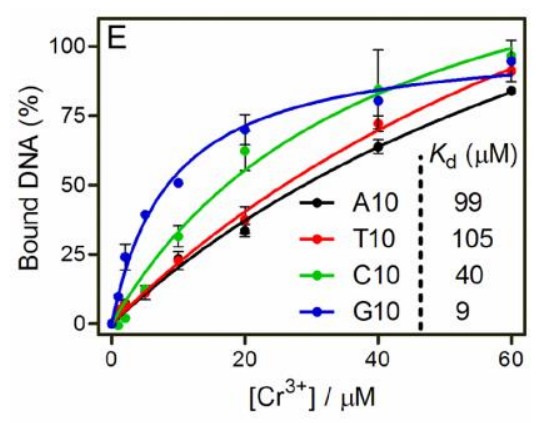

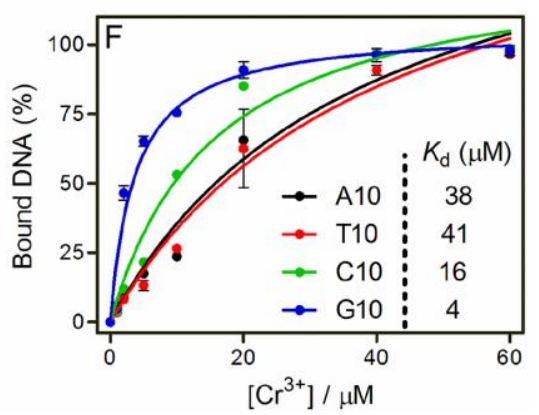

Figure 5. (A) Gel images showing the binding kinetics of $100 \mu \mathrm{M} \mathrm{Cr}^{3+}$ with $1 \mu \mathrm{M} 10$-mer DNA homopolymers. (B) Kinetics of $\mathrm{Cr}^{3+}$ and DNA binding quantified from (A). (C) Gel images showing DNA mixed with EDTA (10 mM) first and then adding $\mathrm{Cr}^{3+}$ (lane 2); and DNA mixed with $\mathrm{Cr}^{3+}$ first and then adding EDTA (10 mM, lane 3). (D) Quantification of the last two lanes in (C) normalized to the first lane. The fraction of bound DNA as a function of $\mathrm{Cr}^{3+}$ concentration after (E) $4 \mathrm{~h}$ and (F) $24 \mathrm{~h}$ incubation. All the assay were performed in $25 \mathrm{mM}$ $\mathrm{NaCl}, 50 \mathrm{mM}$ MES, pH 6.5.

Effect of $\mathbf{C r}^{3+}$ hydrolysis. Metal ions can be hydrolyzed at high $\mathrm{pH}$. Chromium hexahydrate is a strong acid with a $\mathrm{p} K_{\mathrm{a}} 1$ of $\sim 4$. The above studies showed that at a slight basic $\mathrm{pH}$ of $7.6, \mathrm{Cr}^{3+}$ failed to crosslink the DNAzyme, which may be due to hydrolysis. To test this, an experiment was designed as outlined in Figure 6A. Before adding DNA, a few $\mathrm{Cr}^{3+}$ solutions were respectively stored in a series of buffers with different $\mathrm{pH}$ 's. At designated time points, the $\mathrm{pH}$ was adjusted to $\mathrm{pH} 6.5$ (the optimal $\mathrm{pH}$ for $\mathrm{DNA}$ and $\mathrm{Cr}^{3+}$ binding), followed by an immediately 
addition of $1 \mu \mathrm{M}$ FAM-C10 DNA. After $2 \mathrm{~h}$ incubation, the fluorescence intensity was measured to quantify the fraction of bound DNA.

When stored at $\mathrm{pH} 3, \mathrm{Cr}^{3+}$ still fully quenched the fluorescence even after storing for $24 \mathrm{~h}$, suggesting quantitative DNA binding (Figure 6B, red trace) and thus the lack of $\mathrm{Cr}^{3+}$ hydrolysis at $\mathrm{pH}$ 3. Note the $\mathrm{pH}$ of a $100 \mathrm{mM} \mathrm{Cr}^{3+}$ stock solution is around 3. At $\mathrm{pH} 5, \mathrm{Cr}^{3+}$ still largely retained the binding ability after $24 \mathrm{~h}$ storage, while incubation $\mathrm{Cr}^{3+}$ at $\mathrm{pH} 7$ has gradually weakened its DNA binding over time (Figure 6B, yellow trace). The hydrolysis kinetic of $\mathrm{Cr}^{3+}$ at pH 9 is even faster, as indicated by the sharp decrease of the bound DNA. The DNA binding kinetics in Figure 6B is a reflection of the hydrolysis of $\mathrm{Cr}^{3+}$. Overall, an elevated $\mathrm{pH}$ promotes $\mathrm{Cr}^{3+}$ hydrolysis and decreases DNA binding.

Of note, we initially used a dilute $\mathrm{Cr}^{3+}$ stock solution $(1 \mathrm{mM})$ to study the DNA binding, and obtained inconsistent results at different days, which is probably due to hydrolysis. The $\mathrm{pH}$ of $1 \mathrm{mM} \mathrm{Cr}^{3+}$ is $\sim 6$, at which $\mathrm{Cr}^{3+}$ would gradually hydrolyze, resulting in different DNA binding yields in different days.

We finally explored whether $\mathrm{Cr}^{3+}$ can restore its DNA binding ability after hydrolysis. To test this, the hydrolyzed $\mathrm{Cr}^{3+}$ sample was acidified using $\mathrm{HCl}$. After $1 \mathrm{~h}$ incubation, the sample was further adjusted to $\mathrm{pH}$ 6.5, and the FAM-C10 DNA was added. After $2 \mathrm{~h}$, the fluorescence was significant quenched (Figure 6C), suggesting DNA binding and $\mathrm{Cr}^{3+}$ hydrolysis is reversible. 

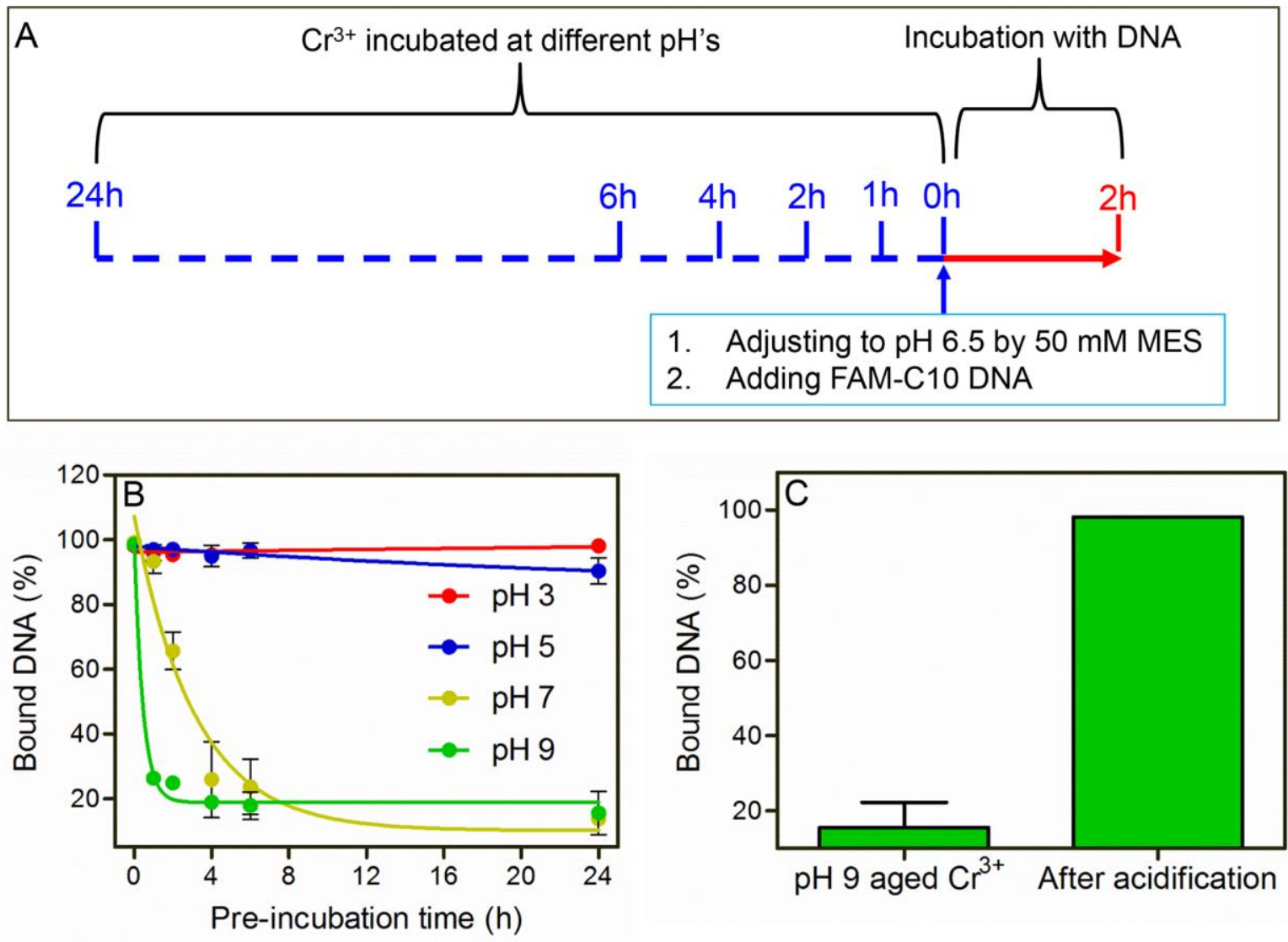

Figure 6. (A) A scheme showing the experiment design to study the effect of $\mathrm{Cr}^{3+}$ hydrolysis on DNA binding. (B) Kinetics of $\mathrm{Cr}^{3+}$ hydrolysis at different $\mathrm{pH}$ 's reflected by the quenching of the FAM-C10 DNA. The pH was buffered by acetate (pH 3 and 5), MES (pH 7) and MOPS (pH 9) for $\mathrm{Cr}^{3+}$ pre-incubation. (C) The DNA binding ability of hydrolyzed $\mathrm{Cr}^{3+}$ sample before and after acidification.

\section{Conclusions}

DNA/metal interaction is a highly important topic for drug development, toxicology, materials chemistry, and biosensor development. ${ }^{41-45}$ Compared to many other common metals, the work on $\mathrm{Cr}^{3+}$ has been quite limited. In this work, we studied the interaction between $\mathrm{Cr}^{3+}$ and DNA 
by employing the Ce13d DNAzyme and four types of DNA homopolymers. Different from most previously studied metal ions, $\mathrm{Cr}^{3+}$ is featured by an extremely slow ligand exchange rate,

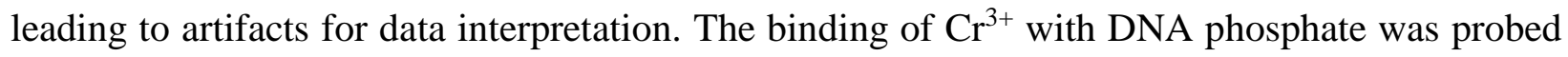
by the Ce13d, which is based on the fact that the chemical role of $\mathrm{Cr}^{3+}$ in Ce13d catalysis is related to $\mathrm{Cr}^{3+}$ binding to the scissile phosphate. Unlike the same reaction catalyzed by $\mathrm{Ce}^{3+}$, where the log of cleavage rate increases with $\mathrm{pH}$ with a slope of $0.4, \mathrm{pH}$ has a much smaller effect for $\mathrm{Cr}^{3+}$. This suggests that $\mathrm{Cr}^{3+}$ undergoes other reactions that counteract the normal $\mathrm{pH}$ effect, likely related to hydrolysis. Using inorganic phosphate as a probe, we demonstrated that $\mathrm{Cr}^{3+}$ binding to the DNA backbone phosphate is weak, reversibly, and likely through electrostatic interactions.

The coordination between $\mathrm{Cr}^{3+}$ and DNA bases was evidenced by $\mathrm{Cr}^{3+}$-mediated DNAzyme inter-strand crosslinking, forming highly stable products that can survive denaturing gel electrophoresis and even EDTA incubation. The coordination of $\mathrm{Cr}^{3+}$ with different bases was further studied using DNA homopolymers. $\mathrm{Cr}^{3+}$ quenches the fluorophore labeled on DNA upon binding, which provides a facile way to follow the binding kinetics. $\mathrm{Cr}^{3+}$ directly coordinates with all the four DNA bases, forming ultrastable metallated DNA, which cannot be dissociated by EDTA. This is attributable to the slow ligand exchange of $\mathrm{Cr}^{3+}$. The binding kinetic of each base follows the order of $\mathrm{G}>\mathrm{C}>\mathrm{T} \approx \mathrm{A}$, and this kinetic order also determines the measured apparent $K_{\mathrm{d}}$. A faster binding and longer reaction time results in a higher apparent binding affinity, where the G10 DNA has the tightest $K_{\mathrm{d}}$ of $4 \mu \mathrm{M} \mathrm{Cr}{ }^{3+}$ after $24 \mathrm{~h}$ reaction. The actual $K_{\mathrm{d}}$ is likely to be much lower since the binding is kinetically controlled and true equilibrium was not reached even after $24 \mathrm{~h} . \mathrm{Cr}^{3+}$ loses its DNA binding ability at higher $\mathrm{pH}$ due to hydrolysis, and this process can be reversed by lowering the $\mathrm{pH}$. Taken together, this work 
provides comprehensive information about $\mathrm{Cr}^{3+}$ and DNA binding, which will enable consistent experimental results for future studies. It has also clarified some inconsistent reports from the

previous literature, mainly due to the hydrolysis and slow binding kinetics of $\mathrm{Cr}^{3+}$. The insights from this work can also help understand the toxicity of chromium.

\section{Acknowledgement}

This work is supported by the University of Waterloo, the Natural Sciences and Engineering Research Council of Canada (NSERC), Foundation for Shenghua Scholar of Central South University and the National Natural Science Foundation of China (Grant No. 21301195). W.Z. is supported by the Fellowship from the China Scholarship Council (CSC, Grant No. 201406370116).

\section{References}

(1) Vaidyanathan, V. G.; Asthana, Y.; Nair, B. U. Dalton Trans 2013, 42, 2337-2346.

(2) Costa, M.; Klein, C. B. Crit. Rev. Toxicol. 2006, 36, 155-163.

(3) Tsapakos, M. J.; Wetterhahn, K. E. Chem Biol Interact 1983, 46, 265-277.

(4) Zhitkovich, A. Chem. Res. Toxicol. 2005, 18, 3-11.

(5) Levina, A.; Zhang, L.; Lay, P. A. J. Am. Chem. Soc. 2010, 132, 8720-8731.

(6) Stearns, D. M.; Kennedy, L. J.; Courtney, K. D.; Giangrande, P. H.; Phieffer, L. S.; Wetterhahn, K. E. Biochemistry 1995, 34, 910-919.

(7) Bose, R. N.; Moghaddas, S.; Mazzer, P. A.; Dudones, L. P.; Joudah, L.; Stroup, D. Nucleic Acids Res. 1999, 27, 2219-2226. 
(8) Salnikow, K.; Zhitkovich, A. Chem. Res. Toxicol. 2007, 21, 28-44.

(9) Zhitkovich, A.; Voitkun, V.; Kluz, T.; Costa, M. Environ. Health Perspect. 1998, 106 Suppl 4, 969-974.

(10) Xu, J.; Bubley, G. J.; Detrick, B.; Blankenship, L. J.; Patierno, S. R. Carcinogenesis 1996, $17,1511-1517$.

(11) Zhitkovich, A.; Voitkun, V.; Costa, M. Carcinogenesis 1995, 16, 907-913.

(12) Zhitkovich, A.; Song, Y.; Quievryn, G.; Voitkun, V. Biochemistry 2001, 40, 549-560.

(13) Zhitkovich, A.; Shrager, S.; Messer, J. Chem. Res. Toxicol. 2000, 13, 1114-1124.

(14) Morse, J. L.; Luczak, M. W.; Zhitkovich, A. Chem. Res. Toxicol. 2013, 26, 1591-1598.

(15) Quievryn, G.; Peterson, E.; Messer, J.; Zhitkovich, A. Biochemistry 2003, 42, 1062-1070.

(16) Helm, L.; Merbach, A. E. Chem. Rev. 2005, 105, 1923-1959.

(17) Wolf, T.; Kasemann, R.; Ottenwälder, H. Carcinogenesis 1989, 10, 655-659.

(18) Madhusudanan, K.; Katti, S.; Vijayalakshmi, R.; Nair, B. J. Mass Spectrom. 1999, 34, 880-884.

(19) Salnikow, K.; Zhitkovich, A.; Costa, M. Carcinogenesis 1992, 13, 2341-2346.

(20) Arakawa, H.; Ahmad, R.; Naoui, M.; Tajmir-Riahi, H.-A. J. Biol. Chem. 2000, 275, 10150-10153.

(21) O'Brien, T. J.; Ceryak, S.; Patierno, S. R. Mutat. Res. 2003, 533, 3-36.

(22) Levina, A.; Lay, P. A. Chem. Res. Toxicol. 2008, 21, 563-571.

(23) Raja, N. S.; Nair, B. U. Toxicology 2008, 251, 61-65.

(24) Huang, P.-J. J.; Lin, J.; Cao, J.; Vazin, M.; Liu, J. Anal. Chem. 2014, 86, 1816-1821.

(25) Sigel, R. K. O.; Sigel, H. Acc. Chem. Res. 2010, 43, 974-984.

(26) Sigel, R. K. O.; Pyle, A. M. Chem. Rev. 2007, 107, 97-113. 
(27) Ward, W. L.; Plakos, K.; DeRose, V. J. Chem. Rev. 2014, 114, 4318-4342.

(28) Lu, Y. Inorg. Chem. 2006, 45, 9930-9940.

(29) Vazin, M.; Huang, P.-J. J.; Matuszek, Ż.; Liu, J. Biochemistry 2015, 54, 6132-6138.

(30) Zhou, W.; Vazin, M.; Yu, T.; Ding, J.; Liu, J. Chem. Eur. J. 2016, 22, 9835-9840

(31) Huang, P.-J. J.; Liu, J. Anal. Chem. 2014, 86, 5999-6005.

(32) Lennartson, A. Nat Chem 2014, 6, 942-942.

(33) O'Brien, T.; Mandel, H. G.; Pritchard, D. E.; Patierno, S. R. Biochemistry 2002, 41, $12529-12537$.

(34) Snow, E. T. Environ. Health Perspect. 1994, 102 Suppl 3, 41-44.

(35) Deans, A. J.; West, S. C. Nature Reviews Cancer 2011, 11, 467-480.

(36) Crimp, S. J.; Spiccia, L.; Krouse, H. R.; Swaddle, T. W. Inorg. Chem. 1994, 33, 465-470.

(37) Quievryn, G.; Messer, J.; Zhitkovich, A. Biochemistry 2002, 41, 3156-3167.

(38) Zhou, W.; Zhang, Y.; Huang, P.-J. J.; Ding, J.; Liu, J. Nucleic Acids Res. 2016, 44, 354363.

(39) Torabi, S.-F.; Lu, Y. J. Mol. Evol. 2015, 81, 225-234.

(40) Wang, F.; Liu, J. Nanoscale 2014, 6, 7079-7084.

(41) Xiang, Y.; Lu, Y. Inorg. Chem. 2014, 53, 1925-1942.

(42) Jamieson, E. R.; Lippard, S. J. Chem. Rev. 1999, 99, 2467-2498.

(43) McLaughlin, C. K.; Hamblin, G. D.; Sleiman, H. F. Chem. Soc. Rev. 2011, 40, 5647-5656.

(44) Zhang, X. B.; Kong, R. M.; Lu, Y. Annu. Rev. Anal. Chem. 2011, 4, 105-128.

(45) Herrera, J. M.; Mendes, F.; Gama, S.; Santos, I.; Navarro Ranninger, C.; Cabrera, S.; Quiroga, A. G. Inorg. Chem. 2014, 53, 12627-12634. 
